\title{
Bioanalysis
}

\section{Relative distribution of $\mathrm{Gb}_{3}$ isoforms/analogs in NOD/SCID/Fabry mice tissues determined by tandem mass spectrometry}

\begin{abstract}
Aim: Fabry disease is a lysosomal storage disorder leading to glycosphingolipid accumulation in different organs, tissues and biological fluids. The development of a Fabry disease gene therapy trial is underway in Canada. A tool to determine the distribution of $\mathrm{Gb}_{3}$ biomarkers in tissues of Fabry mice might be applicable to monitor the effect of gene therapy. Results \& methodology: An ultra-performance LC-MS/MS (UPLC-MS/MS) method for the analysis of $22 \mathrm{~Gb}_{3}$ isoform/analogs in various Fabry mice tissues was developed and validated. Marked variation in biomarker organ distribution was found with higher levels in the spleen, followed by the small intestine, kidneys, lungs, heart, liver and brain. Conclusion: The devised method is sensitive and useful for the evaluation of biomarker profiles in Fabry mice.
\end{abstract}

First draft submitted: 6 May 2016; Accepted for publication: 4 July 2016;

Published online: 15 August 2016

Keywords: Fabry disease $\bullet$ globotriaosylceramide $\bullet$ isoforms/analogs $\bullet$ liquid-liquid extraction $\bullet \mathrm{MS} \bullet \mathrm{NOD} / \mathrm{SCID}$ mice $\bullet$ organ biomarker distribution

Fabry disease (OMIM 301500) is an X-linked lysosomal storage disorder characterized by the accumulation of glycosphingolipids in organs, tissues and the vascular endothelium, as well as biological fluids. Various mutations in the GLA gene (locus $\mathrm{Xq22.1)}$ lead to deficiency of $\alpha$-galactosidase A ( $\alpha$-gal A, EC 3.2.1.22) enzyme activity responsible for the metabolic catabolism of various glycosphingolipids [1-4]. The disease is associated with over 600 different mutations [5] and characterized by heterogeneous clinical manifestations affecting the kidneys, the heart, the eyes, as well as cerebrovascular diseases (transient ischemic attacks and stroke) [3]. Other symptoms include gastrointestinal problems, intolerance to heat and cold, hypohidrosis and angiokeratomas [2-4]. Males are generally more severely affected with the disease than females, but women might also be severely affected [6]. Moreover, the variability of disease manifestations in females is due to Lyonization and skewed
X-inactivation [7]. The incidence of Fabry disease is probably underestimated owing to the existence of multiple variants of the disease and the difficulty in confirming a diagnosis. It ranges from 1:117 000 to $1: 1300$ [8-10]. It is important to note that the high incidence of Fabry disease has been evaluated by newborn screening programs, where mutations of uncertain pathogenicity were detected.

Regarding treatment, enzyme replacement therapy (ERT) has been shown to be beneficial for Fabry patients [3,11], though not in all cases [12]. Development of antibodies against the infused enzyme has been observed in some patients [13-15]. Other treatments such as chaperone therapy [16,17] and substrate reduction therapy [18] are also under investigation.

Development of gene therapies have also been under investigation for Fabry disease $[19,20]$ and among others, metachromatic leukodystrophy [21,22]. In Canada, a clinical trial of gene therapy (FACTs project) for Fabry patients is in progress using recombi-
Philippe Provençal', Michel Boutin', Shaalee Dworski², Bryan $\mathrm{Au}^{2}$, Jeffrey A Medin ${ }^{2,3}$ \& Christiane Auray-Blais*,1

'Department of Pediatrics, Division of Medical Genetics, Faculty of Medicine \& Health Sciences, Université de Sherbrooke, 3001, 12th Avenue North, Sherbrooke, QC, J1H 5N4 Canada ${ }^{2}$ Institute of Medical Science, Max Bell Research Center, University of Toronto, 101 College Street, Room 5-407, Toronto, ON, M5G 1L7 Canada ${ }^{3}$ Department of Pediatrics, Medical College of Wisconsin, 8701 Watertown Plank Road, MFRC 3018, Milwaukee, WI 53226, USA

*Author for correspondence: Tel.: +1 819346 1110, ext. 14706 Fax: +1 8195645217

christiane.auray-blais@usherbrooke.ca 
nant lentiviruses targeting hematopoietic stem cells for the sustained systemic correction of the enzyme deficiency [23]. Animal models have been extensively used for the study of human genetic diseases, including for Fabry disease. In fact, mouse models have been developed for biochemical, behavioral and neurophysiological Fabry disease studies [24-29]. A mouse model has been developed for the FACTs project (JA Medin) using a nonobese diabetic (NOD)/severe combined immune deficiency (SCID)/Fabry mouse (NSF) [23]. This mouse model shows marked deficiency of $\alpha$-gal A enzyme activity, but no clinical manifestations of the disease. An efficient method was necessary to evaluate Fabry disease biomarkers in the NSF mouse tissues from different organs and plasma samples originating from the gene therapy project.

Accumulation of glycosphingolipids, such as globotriaosylceramide $\left(\mathrm{Gb}_{3}\right)$ isoforms/analogs [30-35], globotriaosylsphingosine (lyso- $\mathrm{Gb}_{3}$ ) and analogs [36-41], and galabiosylceramide $\left(\mathrm{Ga}_{2}\right)$ isoforms/analogs [42], have been described in human plasma and urine. Metabolomic studies using biological fluids from Fabry disease patients have led to the discovery of various isoforms and analogs of $\mathrm{Gb}_{3}[32,33]$. Modifications on the $\mathrm{Gb}_{3}$ fatty acid chain are called 'isoforms,' while modifications on the sphingosine chain are referred to as 'analogs' [34]. Figure 1 shows five groups of $\mathrm{Gb}_{3}$ isoforms/analogs that are characterized as follows: Group 1: $\mathrm{Gb}_{3}$ isoforms with saturated fatty acids; Group 2: $\mathrm{Gb}_{3}$ isoforms/analogs with one extra-double bond (on the sphingosine or fatty acid); Group 3: $\mathrm{Gb}_{3}$ isoforms/analogs with two extra-double bonds (on the sphingosine and fatty acid or both on the fatty acid); Group 4: $\mathrm{Gb}_{3}$ isoforms hydroxylated fatty acid and Group 5: methylated $\mathrm{Gb}_{3}$ isoforms [32]. For Groups 2 and 3, previous MS/MS experiments demonstrated the existence of structural isomers with the extra-double bond on the sphingosine (analogs) or on the fatty acid (isoforms) moieties [32,33]. However, the exact positions of the extra-double bond(s) on the sphingosine or the fatty acid moieties are not known and might be variable. For Group 4, the position of the hydroxyl chemical function is not known and might be variable. Finally, the position of the methylation on $\mathrm{Gb}_{3}$ isoforms of Group 5 was confirmed by MS/MS to be located on the nitrogen atom of the amide linkage [32]. These studies revealed a large number of glycosphingolipids, but there is yet a specific biomarker that is validated for the monitoring of therapy and the optimal time to initiate treatment.

Previous results for the analysis of some organs from NSF mice showed variations in the concentration of $\mathrm{Gb}_{3}$ isoforms and analogs for each organ compared with controls [43]. A recent study with a different Fabry mouse model (C57BL/6 GLA knockout) also showed variations in organ concentration of $\mathrm{Gb}_{3}$ isoforms/analogs; however, this study was limited to heart, kidney, liver and plasma biomarkers [44]. The main objectives of this study were: first, to develop and validate an efficient and robust ultra-performance LC-MS/MS (UPLC-MS/MS) methodology for the analysis of $\mathrm{Gb}_{3}$ isoforms/analogs in a wide range of mouse tissues, including brain, heart, liver, kidneys, small intestine, spleen, lungs, as well as urine and plasma and second, to evaluate the relative distribution

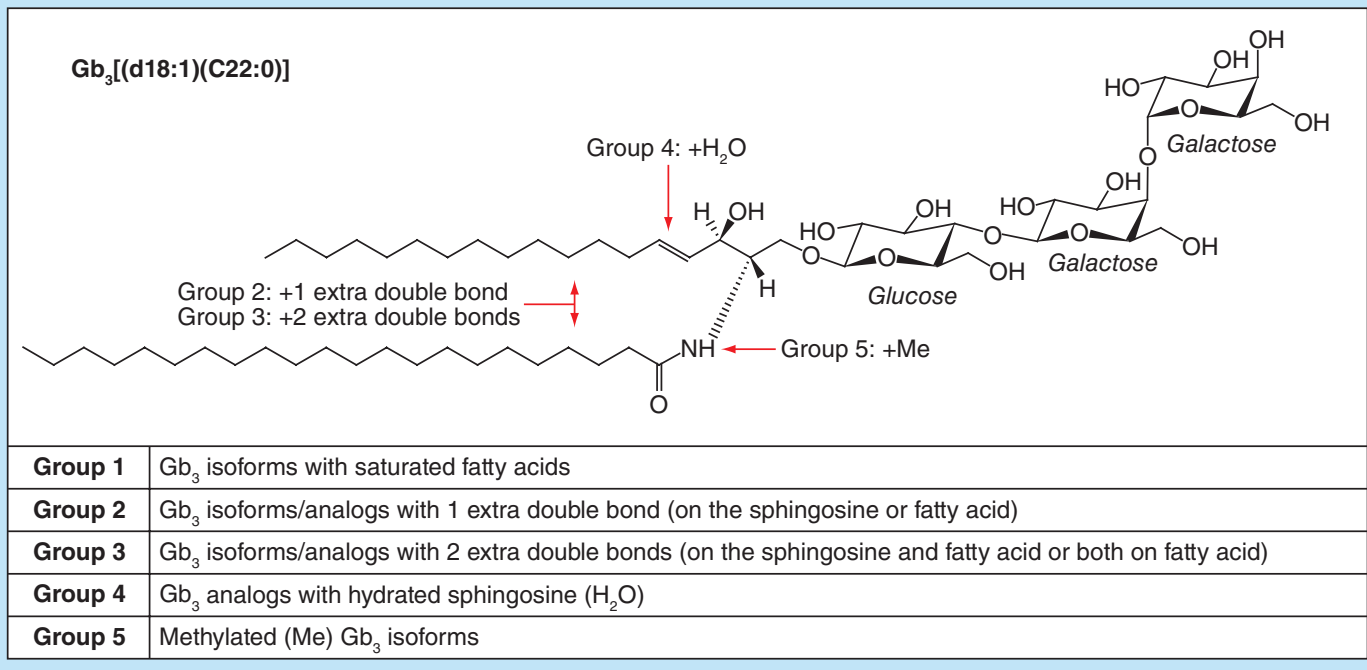

Isoforms: Modifications on the fatty acid chain; Analogs: Modifications on the sphingosine

Figure 1. Chemical structure of globotriaosylceramide biomarkers with the example of $\mathrm{Gb}_{3}[(\mathrm{~d} 18: 1)(\mathrm{C} 22: 0)]$

from Group 1. Groups $2-5$ show the possible modifications on the sphingosine and/or fatty acid chain.G. $b_{3}$ : Globotriaosylceramide. 
of $\mathrm{Gb}_{3}$ isoforms/analogs in each organ and biological fluids of NSF mice and controls.

\section{Materials \& methods}

\section{Chemicals \& reagents}

$N$-Octadecanoyl-D3-ceramide (Gb [(d18:1)(C18:0)D3]) (98+\%), heptadecanoylceramide trihexoside $\left(\mathrm{Gb}_{3}(\mathrm{~d} 18: 1)(\mathrm{C} 17: 0)\right) \quad(98+\%)$ and ceramide trihexoside $\left(\mathrm{Gb}_{3}\right.$ isoform/analog mixture) were purchased from Matreya (PA, USA). HPLC grade tert-butyl methyl ether (MTBE) was from SigmaAldrich (MO, USA). HPLC grade methanol (MeOH) was from EMD Chemicals Inc. (Darmstadt, Germany). Optima LC-MS grade water, ammonium formate (Amm. Form.) (99\%), ACS Reagent grades for both glacial acetic acid and potassium hydroxide $(\mathrm{KOH})$ pellets were from Fisher Scientific (NJ, USA). Formic acid (FA) $(+99 \%)$ was from Acros Organics (NJ, USA).

\section{Nomenclature}

As mentioned previously, $\mathrm{Gb}_{3}$ is a neutral glycosphingolipid composed of an oligosaccharide (galactose $\alpha 1-4$ galactose $\beta 1-4$ glucose) linked to a ceramide, which is composed of a sphingosine and a fatty acid chain coupled by amide linkage (Figure 1). A nomenclature system for $\mathrm{Gb}_{3}$ isoforms and analogs already exists [32]:

where,

$$
\mathrm{Gb}_{3}[(\mathrm{du}: \mathrm{v}) \mathrm{W}(\mathrm{Cx}: \mathrm{y}) \mathrm{z}] \mathrm{M}
$$

- $\mathrm{d}=$ referring to the sphingosine group

- $\mathrm{u}=$ number of carbons in the sphingosine moiety

- $\quad \mathrm{v}=$ number of double bond(s) in the sphingosine moiety

- $\mathrm{W}=$ modification on the sphingosine chain

- $\mathrm{C}=$ referring to the fatty acid group

- $\mathrm{x}=$ number of carbon atoms in the fatty acid moiety

- $y=$ number of carbon-carbon double bond(s) in the fatty acid moiety

- $\mathrm{z}=$ modification of the fatty acid

- $M=$ modification on the nitrogen of the amide linkage

\section{Instrumentation \& parameters}

LC parameters

An Acquity I-class UPLC system (Waters Corp., MA, USA) was used for $\mathrm{Gb}_{3}$ isoform/analog analysis for all mice tissues in various organs. The HSS T3 C18 column (Waters) offered the best separation for all 22 bio- markers under the study. The chromatography parameters for the multiplex relative quantification analysis of $\mathrm{Gb}_{3}$ isoforms/analogs are shown in Tables 1 \& 2 .

\section{MS parameters}

The detection of all $\mathrm{Gb}_{3}$ isoforms/analogs and the $\mathrm{Gb}_{3}[(\mathrm{~d} 18: 1)(\mathrm{C} 18: 0) \mathrm{D} 3]$ internal standard (IS) was performed simultaneously on a Xevo TQ-S (Waters) triple quadrupole MS/MS. ESI was performed in positive mode. Data were acquired by multiple reaction monitoring. The method run time was $11.25 \mathrm{~min}$ and the total analysis between each injection was 12.25 min. Table 3 \& Supplementary Table 1 show the MS parameters.

\section{Tissue homogenization}

The Bead Ruptor 12 Homogenizer was purchased from Omni International (GA, USA). This system allowed uniform homogenization of all types of organ tissues without overheating of samples, thus preventing degradation of metabolites. The homogenization process was done using $2 \mathrm{ml}$ reinforced plastic tubes (Omni International) with five zirconium oxide beads (1.4 $\mathrm{mm}$ diameter, Omni) added to each tube.

\section{IS preparation}

The preparation of the $\left(\mathrm{Gb}_{3}[(\mathrm{~d} 18: 1)(\mathrm{C} 18: 0) \mathrm{D} 3]\right)$ IS was done by adding $1 \mathrm{ml}$ of chloroform $/ \mathrm{MeOH}$ solution (2:1) directly to $0.5 \mathrm{mg}$ of the IS in a commercial vial. The solution was then quantitatively transferred into a 10 -ml volumetric flask and the volume was completed with $\mathrm{MeOH}$ in order to obtain a concentration of $1 \mu \mathrm{g} / 20 \mu \mathrm{l}$. A fivefold dilution with $\mathrm{MeOH}$ was done to achieve a final working solution of $1 \mu \mathrm{g} / 100 \mu \mathrm{l}$. This solution is stable at $4^{\circ} \mathrm{C}$ for at least 2 months.

Table 1. Ultra-performance LC parameters for the relative quantitation of globotriaosylceramide isoforms/analogs in mice tissues.

\begin{tabular}{|ll|}
\hline Parameters & Description \\
\hline Column & Acquity UPLC HSS T3 \\
\hline Dimensions & $2.1 \mathrm{~mm} \times 50 \mathrm{~mm}(1.8 \mu \mathrm{m})$ \\
\hline Column temperature & $30^{\circ} \mathrm{C}$ \\
\hline Injection mode & Partial loop with needle overfill \\
\hline Injection volume & $7.5 \mu \mathrm{l}$ \\
\hline Autosampler temperature & $10^{\circ} \mathrm{C}$ \\
\hline Mobile phase A & $\mathrm{MeOH}+5 \mathrm{mM} \mathrm{Amm}$. Form. $+0.1 \% \mathrm{FA}$ \\
\hline Mobile phase B & $\mathrm{H}_{2} \mathrm{O}+5 \% \mathrm{MeOH}+5 \mathrm{mM} \mathrm{Amm}$. Form. + \\
\hline Weak wash & $0.1 \% \mathrm{FA}$ \\
\hline Strong wash & $50: 50 \mathrm{phase}$ A:phase B \\
\hline
\end{tabular}


Table 2. Ultra-performance LC gradient for the relative quantitation of globotriaosylceramide isoforms/analogs in mice tissues.

\begin{tabular}{lll} 
Flow rate & Time & Mobile phases $(\%)$ \\
\hline $0.5 \mathrm{ml} / \mathrm{min}$ & $0.00 \rightarrow 0.25 \mathrm{~min}$ & $75 \%$ phase A-85\% phase A (linear) \\
\hline $0.5 \mathrm{ml} / \mathrm{min}$ & $0.25 \rightarrow 1.25 \mathrm{~min}$ & $85 \%$ phase A \\
\hline $0.5 \mathrm{ml} / \mathrm{min}$ & $1.25 \rightarrow 7.00 \mathrm{~min}$ & $85 \%$ phase $A-100 \%$ phase A (linear) \\
\hline $0.5 \mathrm{ml} / \mathrm{min}$ & $7.00 \rightarrow 11.00 \mathrm{~min}$ & $100 \%$ phase $A$ \\
\hline $0.5 \mathrm{ml} / \mathrm{min}$ & $11.00 \rightarrow 11.25 \mathrm{~min}$ & $100 \%$ phase $\mathrm{A}-75 \%$ phase A (linear) \\
\hline
\end{tabular}

Murine tissue samples

$\mathrm{NOD} / \mathrm{SCID} /$ Fabry (NSF) mice were produced in the laboratory of JA Medin by the crossing of a homozygous female Fabry $\left(\alpha\right.$-gal $\mathrm{A}^{-/-}$SCID $\left.{ }^{+/+}\right)$with a male NOD/SCID (NS) $\left(\alpha\right.$-gal A ${ }^{+/ 0}$ SCID $\left.^{-/}\right)$for 11 generations. Confirmation of purity of the NSF mice ( $\alpha$-gal $\left.\mathrm{A}^{-1-} \mathrm{SCID}^{-/-}\right)(\mathrm{n}=24)$ strain was achieved by genotyping, enzyme assays and flow analyses [23]. For this study, we analyzed tissues and biological fluids from 24-week-old male NSF mice $(n=9)$, male NS control mice $(\mathrm{n}=2)$, female NSF mice $(\mathrm{n}=9)$ and female NS control mice $(n=3)$. All experiments on animal were carried out within the regulatory requirements. The analysis of tissues from the brain, heart, liver, spleen, lungs, small intestine, kidney and biological fluids, such as plasma and urine, from NSF and control mice (NS) was performed. All samples were stored at $-80^{\circ} \mathrm{C}$ prior to analysis.

\section{Sample preparation \& extraction \\ Tissue sample preparation}

Mouse tissue samples were cut into pieces using a razor blade on a microscope slide over dry ice to maintain the tissue frozen. Approximately $100 \mathrm{mg}$ of tissue was deposited in a 2-ml tube (Omni International) with five ceramic beads. Four hundred microliters $(400 \mu \mathrm{l})$ of $\mathrm{MeOH}$ were added and tissues homogenized for $45 \mathrm{~s}$ using the Bead Ruptor 12 at high intensity $(5 \mathrm{~m} / \mathrm{s})$. The volume made up with $100 \% \mathrm{MeOH}$ to obtain a final

Table 3. ESI-MS/MS parameters for the relative quantitation of globotriaosylceramide isoforms/analogs in mice tissues.

\begin{tabular}{|ll|}
\hline Parameters & Description \\
\hline Operating mode & Multiple reaction monitoring \\
\hline Ionization mode & $\mathrm{ESI}+$ \\
\hline Capillary voltage & $3.2 \mathrm{kV}$ \\
\hline Source temperature & $150^{\circ} \mathrm{C}$ \\
\hline Desolvation gas temperature & $400^{\circ} \mathrm{C}$ \\
\hline Cone gas flow & $150 \mathrm{I} / \mathrm{h}$ \\
\hline Desolvation gas flow & $550 \mathrm{I} / \mathrm{h}$ \\
\hline
\end{tabular}

concentration of $100 \mathrm{mg}$ of tissue $/ \mathrm{ml}$. A second homogenization was performed for $45 \mathrm{~s}$ at low intensity $(3 \mathrm{~m} / \mathrm{s})$. Samples were afterward stored at $-20^{\circ} \mathrm{C}$ until extraction.

\section{Tissue sample \& biological fluid extraction}

The sample extraction was performed by adding $300 \mu \mathrm{l}$ of $\mathrm{MeOH}$ to $100 \mu \mathrm{l}$ of the homogenate to obtain a working concentration of $25 \mu \mathrm{g}$ tissue $/ \mathrm{ml}$. One hundred microliters $(100 \mu \mathrm{l})$ of urine and plasma samples were processed in an identical manner as the homogenate. One hundred $(100 \mu \mathrm{l})$ of the homogenate $(25 \mu \mathrm{g} / \mathrm{ml})$, $100 \mu \mathrm{l}$ of the $\mathrm{Gb}_{3}$ [(d18:1)(C18:0)D3] IS $(1 \mu \mathrm{g} / 100 \mu \mathrm{l})$, $900 \mu \mathrm{l}$ of $\mathrm{MeOH}, 2 \mathrm{ml}$ of MTBE and $300 \mu \mathrm{l}$ of $\mathrm{KOH}$ $(1 \mathrm{M}$ in $\mathrm{MeOH})$ were deposited in a glass tube. After $15 \mathrm{~s}$ of vortex shaking, the samples were incubated at $37^{\circ} \mathrm{C}$ for $30 \mathrm{~min}$. After neutralizing the $\mathrm{pH}$ with $20 \mu \mathrm{l}$ of glacial acetic acid, $2.6 \mathrm{ml}$ of $\mathrm{H}_{2} \mathrm{O}$ and $2 \mathrm{ml}$ of MTBE were added, tubes were vortexed and centrifuged at $4470 \mathrm{~g}$ for $5 \mathrm{~min}$. We collected the organic upper phase and dried it under a stream of nitrogen. We reconstituted the sample into $500 \mu \mathrm{l}$ of phase $\mathrm{A}(\mathrm{MeOH} / 5 \mathrm{mM}$ Amm. Form./0.1\% FA) and $7.5 \mu \mathrm{l}$ was injected onto the UPLC-MS/MS system.

\section{Matrix effect evaluation}

Since the quantity of tissues for some organs was limited, we assessed the intra-organ matrix effect specifically for the brain, heart, kidney, liver, lung, small intestine, spleen tissues and also for plasma by evaluating the MS results obtained after the injection of a sample from each tissue before and after a twofold dilution. The variation upon analysis of the samples of less than $15 \%$ for each tissue from each organ was considered to be acceptable. The inter-organ matrix effect was investigated by evaluating the increase in the response for each biomarker between each organ by adding $50 \mu \mathrm{l}$ of a commercial $\mathrm{Gb}_{3}$ isoform mixture at a concentration of $1.25 \mathrm{mg} / 50 \mathrm{ml}$ to control matrices prior to analysis $\left(\mathrm{Gb}_{3}\right.$ isoforms/analogs from the matrix were subtracted from these results). The increase in the response for inter-organ matrix assays needed to be constant from one tissue to the other, so that the results would not be affected. This process was necessary because of the reduced quantity of tissue available per organ for the validation process.

\section{Method validation}

Intraday (five replicates in a day) and interday (five different days) precision assays (RSD\%) were performed with low- (reduced biomarker concentration levels) and high (high biomarker concentration levels) quality controls (QCs) for biomarkers in NSF liver tissue. We used the same liver tissue from a single NSF male mouse for the preparation of all high-quality controls (HQCs). For 


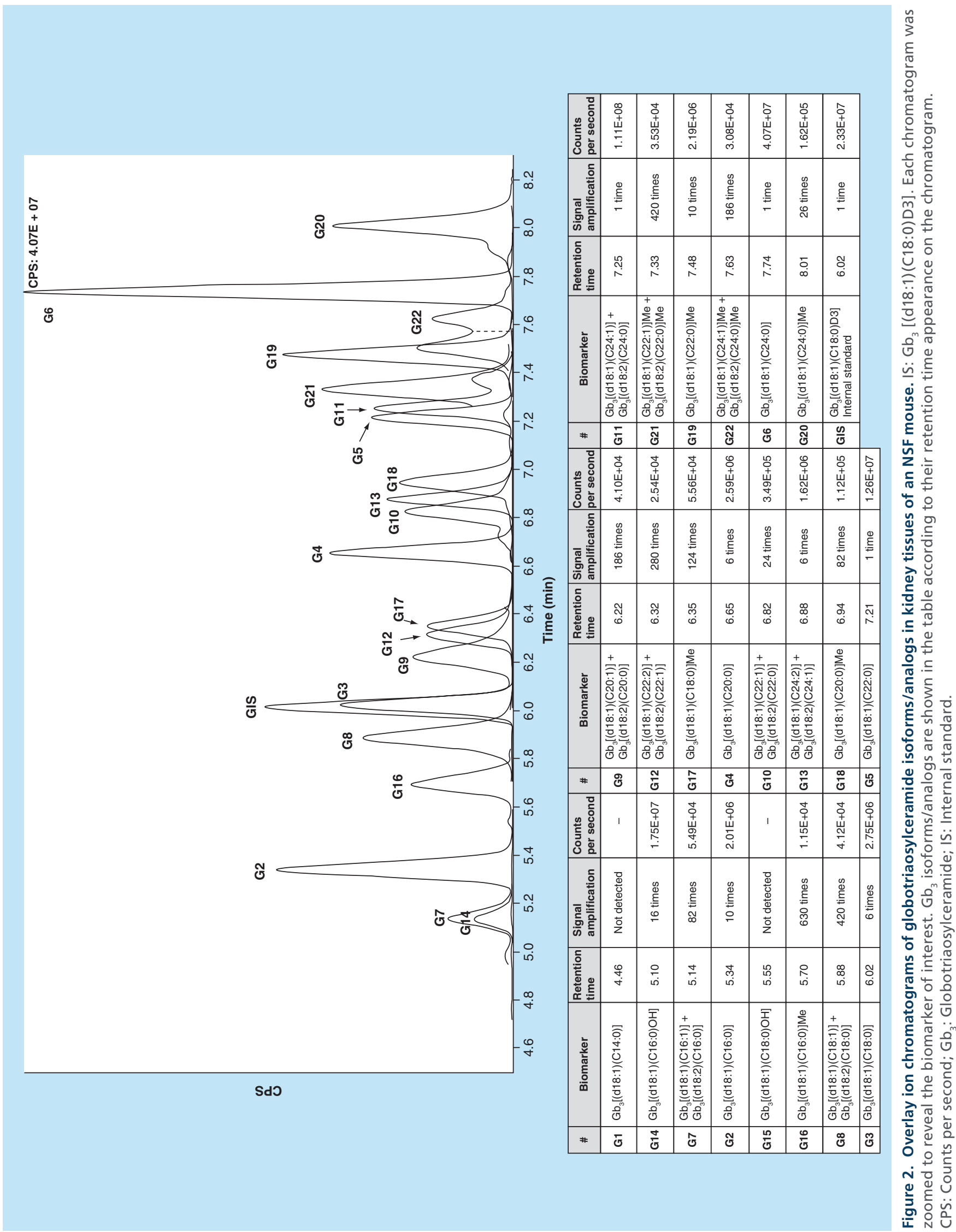



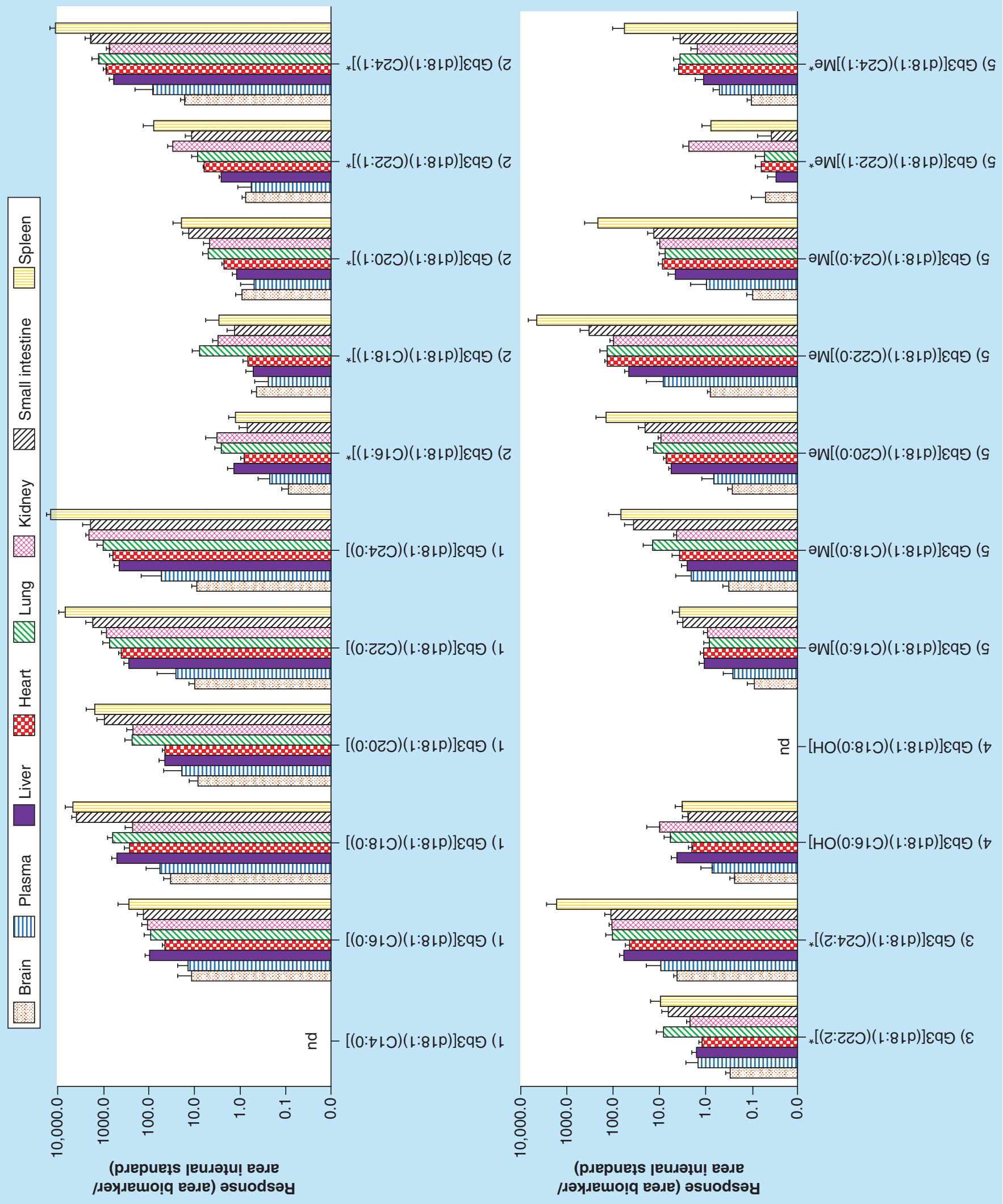
Figure 3. Biomarker profile for globotriaosylceramide isoforms/analogs for different male $(n=9)$ and female $(n=9)$ nonobese diabetic/severe combined immune deficiency/Fabry mice organ tissues: brain, liver, heart, lung, kidney, small intestine and spleen; and plasma samples (females: $n=9$, males: $n=9$ ) (see facing page). Results are expressed as the area of each compound/area of the $\mathrm{Gb}_{3}[(\mathrm{~d} 18: 1)(\mathrm{C} 18: 0) \mathrm{D} 3] \mathrm{IS}$, which is the response factor. The number before each biomarker refers to: Group 1: Gb 3 isoforms with saturated fatty acids; Group 2: $\mathrm{Gb}_{3}$ isoforms/analogs with one extra-double bond (on the sphingosine or fatty acid); Group 3: $\mathrm{Gb}_{3}$ isoforms/analogs with two extra-double bonds (on the sphingosine and fatty acid or both on the fatty acid); Group 4: $\mathrm{Gb}_{3}$ isoforms hydroxylated fatty acid; and Group 5: methylated $\mathrm{Gb}_{3}$ isoforms.

*For $\mathrm{Gb}_{3}$ isoforms/analogs with one or two extra-double bonds, the isoforms with the extra-double bond(s) on the fatty acids were analyzed together with their structural isomers with one extra-double bond on the sphingosine moiety (analogs).

Error bars correspond to the mean plus one standard deviation.

$\mathrm{Gb}_{3}$ : Globotriaosylceramide; IS: Internal standard; nd: Not detected.

low-quality controls (LQCs), NSF heterozygote female mice were used. All interday assays were performed in triplicate and the intraday assay was performed in quintuplicate. The precision was evaluated by measuring the RSD as a percentage. During intraday and interday precision assays, we identified all $\mathrm{Gb}_{3}$ isoforms/analogs using urine and plasma specimens from an untreated, high-excretor Fabry male patient as positive controls. Analyte recoveries from the liquid-liquid extraction process were evaluated by comparing areas of a commercial pool of $\mathrm{Gb}_{3}$ isoforms/analogs spiked $(50 \mu \mathrm{l}$ of a solution of $1.25 \mathrm{mg} / 50 \mathrm{ml}$ ) in each tissue before and after the extraction.

The stability was performed in triplicate with HQCs and LQCs using NSF liver tissue samples left for 3,6 and $24 \mathrm{~h}$ at room temperature $\left(22^{\circ} \mathrm{C}\right)$, stored for 3, 6, 24 and $48 \mathrm{~h}$ in a refrigerator $\left(4^{\circ} \mathrm{C}\right)$, kept for 1,4 and 7 weeks in a freezer $\left(-20^{\circ} \mathrm{C}\right)$ and after three freeze-thaw cycles. The stability of the sample postpreparation was also evaluated for $24 \mathrm{~h}$ in the UPLC autosampler. Adhesion of the analytes to glass and plasticware was also evaluated by performing four consecutive transfers of a mixture of the commercial $\mathrm{Gb}_{3}$ standard $(50 \mu \mathrm{l}$ of a solution of $1.25 \mathrm{mg} / 50 \mathrm{ml})$ in liver tissues with analysis of an aliquot between each transfer.

\section{Relative quantification}

No calibration curves were used for these biomarker analyses because there were no commercially available standard for each biomarker analyzed. The LOD was thus defined as the response equivalent to three-times the signal-to-noise ratio, and ten-times for the LOQ using a low biomarker concentration sample. Therefore, any peaks showing a signal less than ten-times, the noise level was not considered for quantification.

\section{Statistical analyses}

We performed the Mann-Whitney U test to show differences between NSF versus NS control mice and differences between NSF males and females. The Wilcoxon-Friedman Test was used to compare profiles from each organ to plasma profiles of NSF. A principal component analysis test was done to determine the importance of each biomarker in a specific organ. The mean of the response for all organs and biological fluids was also performed to establish profiles of biomarker distribution.

\section{Results \& discussion}

LC

The HSS T3 C18 column allowed a good separation of $\mathrm{Gb}_{3}$ isoforms and analogs based on hydrophobic interactions. $\mathrm{Gb}_{3}$ isoforms with longer fatty acid chains, such as $\mathrm{Gb}_{3}[(\mathrm{~d} 18: 1)(\mathrm{C} 24: 0)]$, were the molecules with the longest retention times owing to their stronger hydrophobic interactions with the column stationary phase. Shorter retention times were observed for isoforms/analogs with the same length of fatty acid chain, but with a higher unsaturation number. The same situation occurred for hydroxylated isoforms. The addition of a methyl group on the amide (Group 5) resulted in a longer retention time. A chromatogram of $\mathrm{Gb}_{3}$ isoforms/analogs in kidney tissues from a NSF mouse is shown in Figure 2.

Since no commercial standards were available for all $\mathrm{Gb}_{3}$ isoforms/analogs, we used the Matreya commercial standard for $\mathrm{Gb}_{3}$ and positive controls consisting of urine and plasma specimens from high-excretor male Fabry patients to establish the optimal gradient and retention time for each isoform/analog.

\section{MS}

Supplementary Table 1 shows all $\mathrm{Gb}_{3}$ isoform/analog MS acquisition parameters for the relative quantification of $22 \mathrm{~Gb}_{3}$ isoforms/analogs and IS, including transitions $(\mathrm{m} / \mathrm{z})$, retention times, cone voltages, collision energies and dwell times. Since no commercial standards exist for all $\mathrm{Gb}_{3}$ isoforms/analogs, we again used the standard $\mathrm{Gb}_{3}$ Matreya commercial mixture and positive Fabry controls as described previously in the chromatography section. A scan of all the product ions was performed at different collision energies to establish which one was produced with the highest intensity. We excluded uncharacteristic fragments such as the loss of a water molecule. Moreover, we excluded fragments corresponding to the sphingosine or to the fatty acid in order to analyze together the structural 


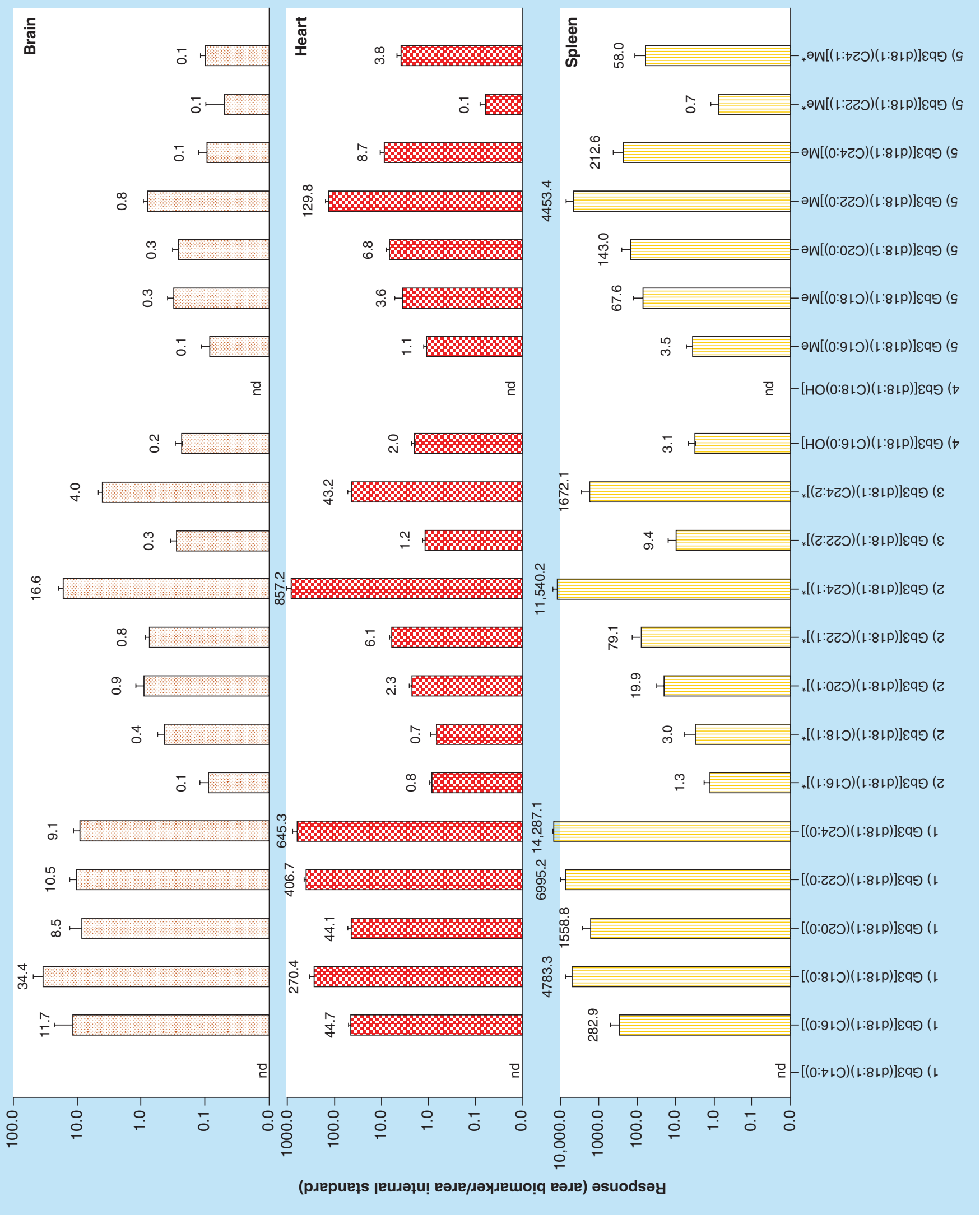


Figure 4. Biomarker profile comparison for globotriaosylceramide isoforms/analogs for brain, heart and spleen of NSF male ( $\mathrm{n}=9$ ) and female Fabry mice tissues $(\mathbf{n}=\mathbf{9})$ (see facing page). Results are expressed as the area of each compound/area of the $\mathrm{Gb} \mathrm{b}_{3}[(\mathrm{~d} 18: 1)$ (C18:0)D3] IS, which is the response factor. The number before each biomarker refers to: Group 1: Gb ${ }_{3}$ isoforms with saturated fatty acids; Group 2: $\mathrm{Gb}_{3}$ isoforms/analogs with one extra-double bond (on the sphingosine or fatty acid); Group 3: $\mathrm{Gb}_{3}$ isoforms/analogs with two extra-double bonds (on the sphingosine and fatty acid or both on the fatty acid); Group 4: Gb 3 isoforms hydroxylated fatty acid; and Group 5: methylated $\mathrm{Gb}_{3}$ isoforms.

*For $\mathrm{Gb}_{3}$ isoforms/analogs with one or two extra-double bonds, the isoforms with the extra-double bond(s) on the fatty acids were analyzed together with their structural isomers with one extra-double bond on the sphingosine moiety (analogs).

Error bars correspond to the mean plus one standard deviation.

$\mathrm{Gb}_{3}$ : Globotriaosylceramide; IS: Internal standard; nd: Not detected.

isomers with extra double bond(s) on the sphingosine and/or on the fatty acid moieties. The fragments monitored for different molecules analyzed corresponded to the dehydrated ceramide fragments. A high sensitivity for each peak was obtained by establishing a precise multiple reaction monitoring transition schedule. A window of $\pm 1 \mathrm{~min}$ was found to be the optimal time for MS data acquisition.

\section{Matrix effects}

Supplementary Table 2 shows the intra-organ matrix effects for $22 \mathrm{~Gb}_{3}$ isoforms/analogs in brain, heart, kidney, liver, lung, small intestine, spleen tissues and plasma. Following are percentages (\%) of the variation of the response (area of a compound/area of the $\mathrm{Gb}_{3}[(\mathrm{~d} 18: 1)(\mathrm{C} 18: 0) \mathrm{D} 3]$ IS) after a twofold dilution for each tissue. The intra-organ matrix variation was calculated by dividing the response of each biomarker before and after a twofold dilution, which was expressed in percentage. There is a small, but acceptable bias. Examples for each isoform/analog of the five groups of biomarkers revealed that $\mathrm{Gb}_{3}[(\mathrm{~d} 18: 1)(\mathrm{C} 16: 0)]$ varied from 5.8 to $12.9 \%$ for this specific isoform; for $\mathrm{Gb}_{3}[(\mathrm{~d} 18: 1)(\mathrm{C} 18: 0)]$, the range was from 3.0 to $10.6 \%$; for $\mathrm{Gb}_{3}[(\mathrm{~d} 18: 1)(\mathrm{C} 20: 0)]$, the range was from 6.6 to $12.7 \%$; for $\mathrm{Gb}_{3}[(\mathrm{~d} 18: 1)(\mathrm{C} 22: 0)]$, the range was from 6.9 to $10.1 \%$; for $\mathrm{Gb}_{3}[(\mathrm{~d} 18: 1)(\mathrm{C} 24: 0)]$, the range was from 5.9 to $10.9 \%$; for $\mathrm{Gb}_{3}[(\mathrm{~d} 18: 1)(\mathrm{C} 18: 1)]+$ $\mathrm{Gb}_{3}[(\mathrm{~d} 18: 2)(\mathrm{C} 18: 0)]$, the range was from 4.1 to $11.4 \%$; for $\mathrm{Gb}_{3}[(\mathrm{~d} 18: 1)(\mathrm{C} 22: 2)]+\mathrm{Gb}_{3}[(\mathrm{~d} 18: 2)(\mathrm{C} 22: 1)]$, the range was from 6.4 to $9.3 \%$; for $\mathrm{Gb}_{3}[(\mathrm{~d} 18: 1)(\mathrm{C} 24: 2)]$ $+\mathrm{Gb}_{3}[(\mathrm{~d} 18: 2)(\mathrm{C} 24: 1)]$, the range was from 7.7 to $10.8 \%$; for $\mathrm{Gb}_{3}[(\mathrm{~d} 18: 1)(\mathrm{C} 16: 0) \mathrm{OH}]$, the range was from 5.6 to $12.4 \%$; and for $\mathrm{Gb}_{3}[(\mathrm{~d} 18: 1)(\mathrm{C} 22: 0)] \mathrm{Me}$, the range varied from 7.3 to $11.1 \%$. In summary, the overall intra-organ matrix effect was less than $13.5 \%$ for the twofold dilution.

Supplementary Table 3 shows the inter-organ matrix effects for $22 \mathrm{~Gb}_{3}$ isoforms/analogs. The response variation was evaluated by calculating the ratio of the mean of the responses $(n=3)$ from each tissue divided by the mean of the response for all tissues added together, then multiplied by one hundred. Examples for each isoform/analog of the five groups of biomarkers show that for $\mathrm{Gb}_{3}[(\mathrm{~d} 18: 1)(\mathrm{C} 16: 0)]$, the response varied from -5.4 to $9.4 \%$; for $\mathrm{Gb}_{3}[(\mathrm{~d} 18: 1)(\mathrm{C} 18: 0)]$, the range was from -11.1 to $10.4 \%$; for $\mathrm{Gb}_{3}[(\mathrm{~d} 18: 1)(\mathrm{C} 20: 0)]$, the range was from -10.4 to $10.5 \%$; for $\mathrm{Gb}_{3}[(\mathrm{~d} 18: 1)(\mathrm{C} 22: 0)]$, the range was from -10.7 to $10.8 \%$; for $\mathrm{Gb}_{3}[(\mathrm{~d} 18: 1)$ $(\mathrm{C} 24: 0)]$, the range was from -10.3 to $11.3 \%$; for $\mathrm{Gb}_{3}[(\mathrm{~d} 18: 1)(\mathrm{C} 18: 1)]+\mathrm{Gb}_{3}[(\mathrm{~d} 18: 2)(\mathrm{C} 18: 0)]$, the range was from -9.8 to $10.1 \%$; for $\mathrm{Gb}_{3}[(\mathrm{~d} 18: 1)(\mathrm{C} 22: 2)]+$ $\mathrm{Gb}_{3}[(\mathrm{~d} 18: 2)(\mathrm{C} 22: 1)]$, the range was from -8.5 to $10.3 \%$; for $\mathrm{Gb}_{3}[(\mathrm{~d} 18: 1)(\mathrm{C} 24: 2)]+\mathrm{Gb}_{3}[(\mathrm{~d} 18: 2)(\mathrm{C} 24: 1)]$, the range was from -5.5 to $10.5 \%$; for $\mathrm{Gb}_{3}[(\mathrm{~d} 18: 1)(\mathrm{C} 16: 0)$ $\mathrm{OH}]$, the range was -7.7 to $9.9 \%$; and for $\mathrm{Gb}_{3}[(\mathrm{~d} 18: 1)$ $(\mathrm{C} 22: 0)] \mathrm{Me}$, the range varied from -6.1 to $12.5 \%$. In summary, the overall inter-organ matrix effect was less than $\pm 13.5 \%$ that provided the possibility to perform the validation process in only one tissue.

\section{Method validation}

The precision for intraday $(\mathrm{n}=5)$ and interday $(\mathrm{n}=5)$ assays for low (a female heterozygote NSF mouse) and high (a male hemizygote NSF mouse) QCs in liver tissues is shown in Supplementary Table 4. Our results indicate that the precision for intraday and interday assays with relative standard deviations (RSDs) is less than $13.7 \%$ for all biomarkers. Recovery assays revealed a range varying from 82 to $96 \%$ for all biomarkers under the study. The LODs and LOQs were expressed as relative response factors for signal-to-noise ratios of 3 and 10, respectively. LODs ranged from 0.001 to 0.005 , and LOQs from 0.003 to 0.015 (area/area IS). The stability results for HQC and LQC samples left for $24 \mathrm{~h}$ at room temperature $\left(22^{\circ} \mathrm{C}\right)$, stored for $48 \mathrm{~h}$ in a refrigerator $\left(4^{\circ} \mathrm{C}\right)$ and kept for 7 weeks in a freezer $\left(-20^{\circ} \mathrm{C}\right)$ showed bias of less than $15 \%$ for all biomarkers. Samples left in the UPLC autosampler were stable for $24 \mathrm{~h}$ (bias < $15 \%$ ). The stability of biomarkers in liver tissues after three freeze-thaw cycles was less than $15 \%$. No evidence of adsorption of the analytes to glass and plasticware was detected.

\section{Analysis of NSF \& control mice tissues in different organs}

The Mann-Whitney $U$ test performed to evaluate differences between biomarker profiles of NSF and NS control mice revealed, as expected, significant differences $(\mathrm{p}<0.05)$ between the two cohorts. 


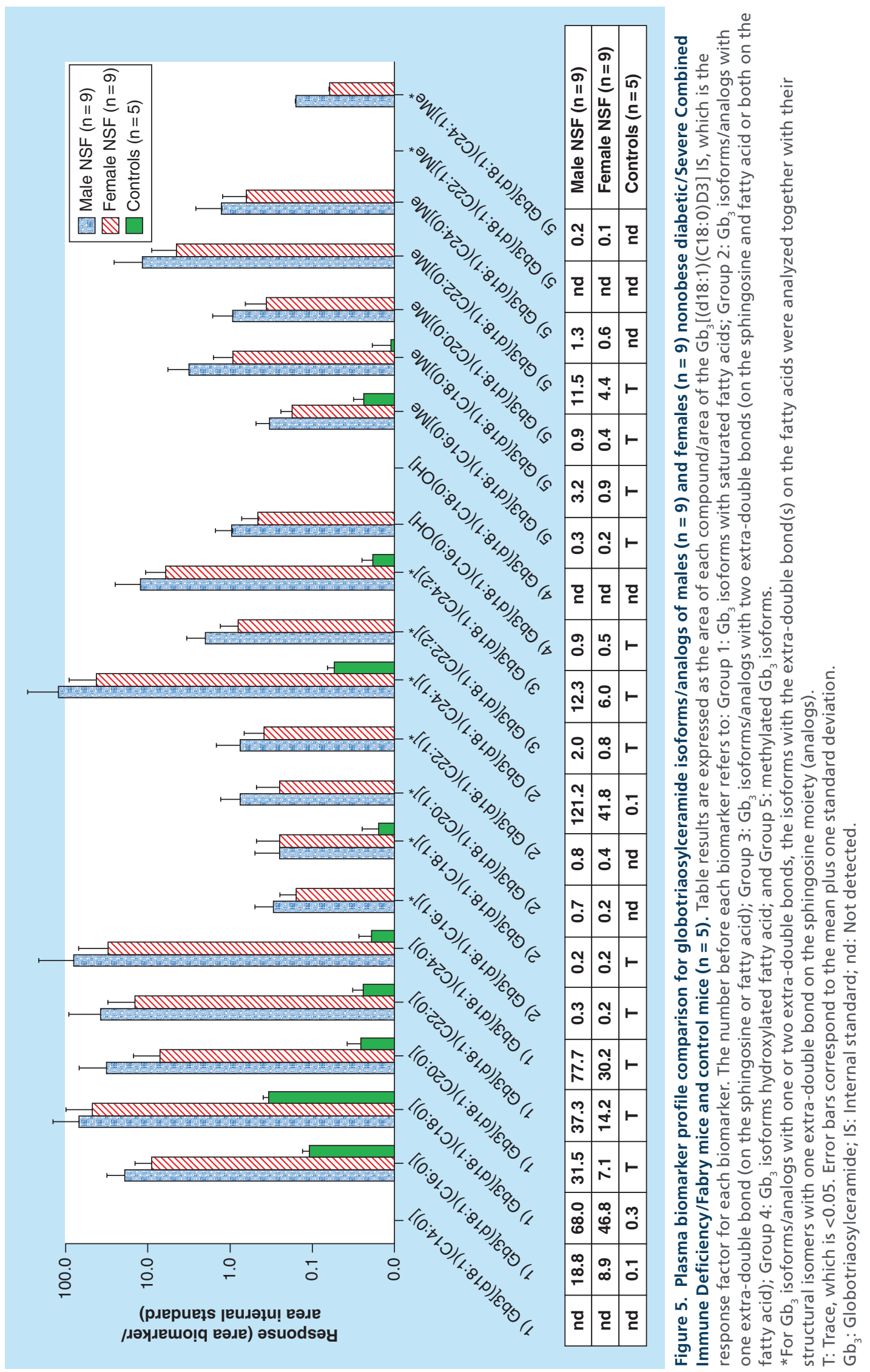


Table 4. Response for each globotriaosylceramide isoform/analog biomarker from different organ tissues of NSF compared to the NSF plasma of the same mice $(n=18)$.

\begin{tabular}{|c|c|c|c|c|c|c|c|}
\hline $\mathrm{Gb}_{3}$ isoforms/analogs & Brain & Heart & Kidney & Liver & Lung & \begin{tabular}{|l} 
Small \\
intestine
\end{tabular} & Spleen \\
\hline $\mathrm{Gb}_{3}[(\mathrm{~d} 18: 1)(\mathrm{C} 14: 0)]$ & \multicolumn{7}{|c|}{ Not detected } \\
\hline \multicolumn{8}{|l|}{$\mathrm{Gb}_{3}[(\mathrm{~d} 18: 1)(\mathrm{C} 16: 0)]$} \\
\hline \multicolumn{8}{|l|}{$\mathrm{Gb}_{3}[(\mathrm{~d} 18: 1)(\mathrm{C} 18: 0)]$} \\
\hline \multicolumn{8}{|l|}{$\mathrm{Gb}_{3}[(\mathrm{~d} 18: 1)(\mathrm{C} 20: 0)]$} \\
\hline \multicolumn{8}{|l|}{$\mathrm{Gb}_{3}[(\mathrm{~d} 18: 1)(\mathrm{C} 22: 0)]$} \\
\hline \multicolumn{8}{|l|}{$\mathrm{Gb}_{3}[(\mathrm{~d} 18: 1)(\mathrm{C} 24: 0)]$} \\
\hline \multicolumn{8}{|l|}{$\begin{array}{l}\mathrm{Gb}_{3}[(\mathrm{~d} 18: 1)(\mathrm{C} 16: 1)] \\
+\mathrm{Gb}_{3}[(\mathrm{~d} 18: 2)(\mathrm{C} 16: 0)]\end{array}$} \\
\hline \multicolumn{8}{|l|}{$\begin{array}{l}\mathrm{Gb}_{3}[(\mathrm{~d} 18: 1)(\mathrm{C} 18: 1)] \\
+\mathrm{Gb}_{3}[(\mathrm{~d} 18: 2)(\mathrm{C} 18: 0)] \\
\end{array}$} \\
\hline \multicolumn{8}{|l|}{ 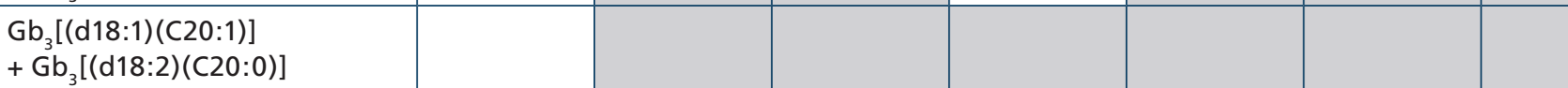 } \\
\hline \multicolumn{8}{|l|}{$\begin{array}{l}\mathrm{Gb}_{3}[(\mathrm{~d} 18: 1)(\mathrm{C} 22: 1)] \\
+\mathrm{Gb}_{3}[(\mathrm{~d} 18: 2)(\mathrm{C} 22: 0)]\end{array}$} \\
\hline \multicolumn{8}{|l|}{$\begin{array}{l}\mathrm{Gb}_{3}[(\mathrm{~d} 18: 1)(\mathrm{C} 24: 1)] \\
+\mathrm{Gb}[(\mathrm{d} 18: 2)(\mathrm{C} 24: 0)]\end{array}$} \\
\hline \multicolumn{8}{|l|}{$\begin{array}{l}\mathrm{Gb}_{3}[(\mathrm{~d} 18: 1)(\mathrm{C} 22: 2)] \\
+\mathrm{Gb}_{3}[(\mathrm{~d} 18: 2)(\mathrm{C} 22: 1)]\end{array}$} \\
\hline \multicolumn{8}{|l|}{$\begin{array}{l}\mathrm{Gb}_{3}[(\mathrm{~d} 18: 1)(\mathrm{C} 24: 2)] \\
+\mathrm{Gb}_{3}[(\mathrm{~d} 18: 2)(\mathrm{C} 24: 1)]\end{array}$} \\
\hline \multicolumn{8}{|l|}{$\mathrm{Gb}_{3}[(\mathrm{~d} 18: 1)(\mathrm{C} 16: 0) \mathrm{OH}]$} \\
\hline $\mathrm{Gb}_{3}[(\mathrm{~d} 18: 1)(\mathrm{C} 18: 0) \mathrm{OH}]$ & \multicolumn{7}{|c|}{ Not detected } \\
\hline \multicolumn{8}{|l|}{$\mathrm{Gb}_{3}[(\mathrm{~d} 18: 1)(\mathrm{C} 16: 0)] \mathrm{Me}$} \\
\hline \multicolumn{8}{|l|}{$\mathrm{Gb}_{3}[(\mathrm{~d} 18: 1)(\mathrm{C} 18: 0)] \mathrm{Me}$} \\
\hline \multicolumn{8}{|l|}{$\mathrm{Gb}_{3}[(\mathrm{~d} 18: 1)(\mathrm{C} 20: 0)] \mathrm{Me}$} \\
\hline \multicolumn{8}{|l|}{$\mathrm{Gb}_{3}[(\mathrm{~d} 18: 1)(\mathrm{C} 22: 0)] \mathrm{Me}$} \\
\hline \multicolumn{8}{|l|}{$\mathrm{Gb}_{3}[(\mathrm{~d} 18: 1)(\mathrm{C} 24: 0)] \mathrm{Me}$} \\
\hline \multicolumn{8}{|l|}{$\begin{array}{l}\mathrm{Gb}_{3}[(\mathrm{~d} 18: 1)(\mathrm{C} 22: 1)] \mathrm{Me}+ \\
\mathrm{Gb}_{3}[(\mathrm{~d} 18: 2)(\mathrm{C} 22: 0)] \mathrm{Me}\end{array}$} \\
\hline $\begin{array}{l}\mathrm{Gb}_{3}[(\mathrm{~d} 18: 1)(\mathrm{C} 24: 1)] \mathrm{Me} \\
+\mathrm{Gb}_{3}[(\mathrm{~d} 18: 2)(\mathrm{C} 24: 0)] \mathrm{Me}\end{array}$ & & & & & & & \\
\hline
\end{tabular}

Figure 3 shows combined biomarker profiles for $\mathrm{Gb}_{3}$ isoforms/analogs for tissues of different male $(\mathrm{n}=9)$ and female $(\mathrm{n}=9)$ NSF mice organs: brain, liver, heart, lung, kidney, small intestine and spleen, and plasma. The highest levels of $\mathrm{Gb}_{3}$ isoforms/analogs in tissues were found in the spleen, small intestine and kidneys, followed by reduced levels in the lungs, heart, liver and brain. Supplementary Tables 5 \& 6 show all the data obtained for each $\mathrm{Gb}_{3}$ isoform/analog for each organ. Data from urine samples ( $\mathrm{n}=6$ NSF males, 1 control) are shown in Supplementary Tables 5 \& 6 . But, due to the small number of samples available, it was not possible to perform comparison analysis. These profiles provide an overview of the distribution of all the biomarkers under study. Taking into account all groups, our results show that biomarkers of Group 1 corresponding to $\mathrm{Gb}_{3}$ isoforms with $\mathrm{C} 16: 0$ to $\mathrm{C} 24: 0$ fatty acids and the isomer mixture $\left(\mathrm{Gb}_{3}[(\mathrm{~d} 18: 1)(\mathrm{C} 24: 1)]+\mathrm{Gb}_{3}[(\mathrm{~d} 18: 2)(\mathrm{C} 24: 0)]\right)$ from Group 2 were the most abundant. Overall, isoforms and analogs with longer fatty acid chain were the most abundant within each group.

Figure 4 shows the relative abundance (or response factor $=$ area of each compound/area of the $\mathrm{Gb}_{3}[(\mathrm{~d} 18: 1)$ (C18:0)D3] IS) of $\mathrm{Gb}_{3}$ isoforms/analogs for brain, 
heart and spleen tissues from 18 NSF mice (males: $\mathrm{n}=9$, and females: $\mathrm{n}=9$ ). The overall distribution pattern for each $\mathrm{Gb}_{3}$ isoforms/analogs is quite similar for the brain, heart and spleen, but major differences in the relative abundance levels were detected for each of these tissues. For example, some $\mathrm{Gb}_{3}$ isoforms or analogs were a 1000-times more abundant in the spleen compared with brain tissues. It is also important to highlight the presence of methylated $\mathrm{Gb}_{3}$ isoforms in all the different tissues analyzed suggesting that this biochemical modification is generated directly in the tissues and is not only a metabolization process of $\mathrm{Gb}_{3}$ in the liver prior to its urinary excretion. It supports our hypothesis that methylated $\mathrm{Gb}_{3}$ might be an intermediate compound conducting to the formation of lyso- $\mathrm{Gb}_{3}$ [32].

A comparison between the relative levels of $\mathrm{Gb}_{3}$ isoforms/analogs in plasma from male $(\mathrm{n}=9)$ and female $(\mathrm{n}=9) \mathrm{NOD} / \mathrm{SCID} /$ Fabry mice, and NS control mice $(\mathrm{n}=5)$ is shown in Figure 5. The Mann-Whitney $\mathrm{U}$ test of the results showed significant differences between NSF mice and NS (controls). However, some $\mathrm{Gb}_{3}$ isoforms/analogs, such as $\mathrm{Gb}_{3}[(\mathrm{~d} 18: 1)(\mathrm{C} 16: 0)]$, $\mathrm{Gb}_{3}[(\mathrm{~d} 18: 1)(\mathrm{C} 18: 0)]$ and $\mathrm{Gb}_{3}[(\mathrm{~d} 18: 1)(\mathrm{C} 24: 1)]+$ $\mathrm{Gb}_{3}[(\mathrm{~d} 18: 2)(\mathrm{C} 24: 0)]$, were detected in control mice. This figure also shows increased relative levels of biomarkers from Group 1 for both male and female Fabry mice. Analyses of plasma showed that $\mathrm{Gb}_{3}[(\mathrm{~d} 18: 1)(\mathrm{C} 14: 0)]$, $\mathrm{Gb}_{3}[(\mathrm{~d} 18: 1)(\mathrm{C} 18: 0) \mathrm{OH}]$ and $\mathrm{Gb}_{3}[(\mathrm{~d} 18: 1)(\mathrm{C} 22: 1)] \mathrm{Me}+$ $\mathrm{Gb}_{3}[(\mathrm{~d} 18: 2)(\mathrm{C} 22: 0)]$ Me were not detected.

We performed the Wilcoxon-Friedman test in order to compare the relative levels of each $\mathrm{Gb}_{3}$ isoform/ analog from each organ to the relative plasma level for each $\mathrm{Gb}_{3}$ isoform/analog from NSF mice (see Table 4). Plasma $\mathrm{Gb}_{3}$ isoform/analog levels were thus considered as the reference value. We also found that biomarkers from Group $3 \mathrm{~Gb}_{3}[(\mathrm{~d} 18: 1)(\mathrm{C} 22: 2)]+\mathrm{Gb}_{3}[(\mathrm{~d} 18: 2)$ (C22:1)] were not statistically significantly increased in the heart, kidneys and liver, as well as $\mathrm{Gb}_{3}[(\mathrm{~d} 18: 1)$ $(18: 0)] \mathrm{Me}$ in the heart and liver. In the brain, half of the biomarker relative quantification levels were not significant. The rest of the isoforms/analogs from each tissue showed a significant difference when compared with plasma. Our data show that, in general, each organ has a unique profile, which is different from the profile in plasma. This might provide an insight into the reason why some organs are more affected than others by the accumulation of $\mathrm{Gb}_{3}$ isoforms/analogs.

The results of the principal component analysis test performed on each organ revealed that for all organs, there was no specific biomarker which showed statistical differences compared with another. Thus, we did not observe a tendency in the variation of a biomarker, which might lead to a physiological explanation (Supplementary Figure 1).

\section{Conclusion}

This study reports an efficient and robust UPLC-MS/ MS methodology for the analysis of $22 \mathrm{~Gb}_{3}$ isoforms/ analogs in various mouse tissues, such as the brain, heart, liver, kidneys, small intestine, spleen, lungs, as well as urine and plasma. The validation of this method showed a precision for intraday and interday assays with RSDs less than $13.7 \%$ and recoveries varying from 82 to $96 \%$. All validation criteria have been met, and the assay is robust. This MS/MS multiplex method allowed the relative quantification of various $\mathrm{Gb}_{3}$ isoform/analog biomarkers in $11.25 \mathrm{~min}$ for tissue extracts and biological fluids of NSF mice and NS controls under the study.

We found that $\mathrm{Gb}_{3}$-related isoforms with saturated fatty acids from Group 1 were highly increased in all NSF tissues. Moreover, isoforms and analogs with longer fatty acid chains were found to be the most abundant in all groups.

The study results reveal higher relative levels of $\mathrm{Gb}_{3}$ isoforms/analogs in the spleen, small intestine and kidneys, followed by the lungs, heart and liver. Among the tissues analyzed, the brain showed the lowest level for $\mathrm{Gb}_{3}$ isoforms/analogs. The distribution profile for each $\mathrm{Gb}_{3}$ isoform/analog is quite similar for the brain, heart and spleen, but major relative quantification differences were observed between each of these tissues. In fact, some $\mathrm{Gb}_{3}$ isoforms or analogs showed a 1000 -fold increase in the spleen tissues compared with brain tissues. Methylated $\mathrm{Gb}_{3}$ isoforms were detected in every NSF tissue samples analyzed suggesting that these molecules are produced directly in the tissues and are not only metabolites generated at the liver level.

By comparing biomarker profile of each organ, we established significant differences for the majority of $\mathrm{Gb}_{3}$ isoforms/analogs. If the same applies to humans, Fabry patients presenting higher biomarker $\mathrm{Gb}_{3}$ concentration levels in tissues of some organs (and eventually in biological fluids) might have persistent clinical manifestations due to insufficient lowering of these high levels even with ERT.

In summary, the marked deficiency of lysosomal $\alpha$-galactosidase $\mathrm{A}$ in the NOD/SCID/Fabry mouse is associated with statistically significant differences between biomarker profiles from NSF compared with NS control mice despite the observation that the enzyme defect does not appear to affect the health or longevity of the mutant animals. It is tempting to speculate that the tissue damage occurring as a result of the enzyme defect in humans is caused by the accumulation of $\mathrm{Gb}_{3}$ isoforms/analogs that are quantitatively less important and therefore less toxic in the NSF mouse. A comparison of the biomarker profiles of tissues from patients affected with Fabry disease with the biomarker 
profiles of tissues from NSF mice might be particularly illuminating. Similarly, a comparison of the biomarker profiles of patients with clinically severe Fabry disease compared with the profiles of patients with the same GLA mutation, but significantly less severe clinical disease, may reveal an important difference in the relative tissue toxicity of different $\mathrm{Gb}_{3}$ isoforms/analogs. Therefore, the MS method developed herein achieved its goal by providing a powerful tool for the analysis of tissue samples from mice organs, which might be applicable to plasma of patients recruited for a Fabry disease gene therapy clinical trial. It might also lead to better biomarkers for monitoring patients affected with Fabry disease.

\section{Future perspective}

A technological transfer of this method will be done to analyze biological fluids of Fabry patients receiving gene therapy. This method also provides the possibility to analyze kidney biopsies from Fabry patients. Correlation studies between the genotype from Fabry patients and their biomarker profiles will be performed for a better understanding of the disease. Furthermore, the main goal for this study was to apply this methodology to gene therapy with a specific Fabry mouse model. However, this biomarker methodology could be applied to evaluate other treatment options for Fabry patients, such as substrate reduction therapy or chaperone therapy. Indeed, research trials involving the evaluation of the efficacy of various treatments will necessitate robust biomarker analysis. One interesting perspective would be to evaluate the diurnal variation of each $\mathrm{Gb}_{3}$ isoform/analog in urine over three ERT cycles, which might explain some variations encountered in Fabry patients specimens collected at different times of day. Moreover, we decided to focus first on $\mathrm{Gb}_{3}$ isoforms/analogs, since lyso- $\mathrm{Gb}_{3}$ is about 1000times less abundant in Fabry patients. Nevertheless, lyso- $\mathrm{Gb}_{3}$ and its analogs are part of future work.

\section{Supplementary data \\ To view the supplementary data that accompany this paper please visit the journal website at: www.future-science.com/ doi/full/10.4155/bio-2016-0116}

\section{Acknowledgements}

The authors sincerely thank JTR Clarke for his expertise and insights. The authors also acknowledge Waters Corporation for their technical and scientific support.

\section{Disclaimer}

The funding organization played no role in the design of the study, the interpretation of data or the preparation of this manuscript.

\section{Financial \& competing interests disclosure}

This research was funded by a Grant-in-Aid of research from the Canadian Institutes of Health Research (CIHR, 129737). The authors have no other relevant affiliations or financial involvement with any organization or entity with a financial interest in or financial conflict with the subject matter or materials discussed in the manuscript apart from those disclosed.

No writing assistance was utilized in the production of this manuscript.

\section{Ethical conduct of research}

Animal studies were performed under an approved Animal Use Protocol from the University Health Network, Toronto, ON, Canada.

\section{Executive summary}

\section{Background}

- The distribution of glycosphingolipids in different organs and biological fluids from Fabry mice remains an important step toward better understanding the pathophysiology of this complex disease and the treatment of affected patients.

\section{Experimental}

- Homogenization of tissues of the brain, heart, liver, kidneys, small intestine, spleen, lungs resulted in efficient extraction of biomarkers and the subsequent MS analysis of globotriaosylceramide $\left(\mathrm{Gb}_{3}\right)$ isoforms/analogs in Fabry mice and controls.

\section{Results \& discussion}

- Twenty-two $\mathrm{Gb}_{3}$ isoforms/analogs analyzed in a short $11.25 \mathrm{~min}$ MS validated assay showed major differences in organ tissue distributions in Fabry mice compared with normal controls, the highest relative levels being found in the spleen, followed by the small intestine, kidneys, lungs, heart, liver and brain. Marked differences in the relative quantitative levels were also observed between various isoforms in different organs.

\section{Conclusion}

- The proposed method allows efficient glycosphingolipid analysis of murine tissues and biological fluids and provides useful information about organ tissue distributions for these biomarkers. This powerful MS tool will be applicable to plasma samples from Fabry patients in order to monitor the efficacy of Fabry patients treated in a clinical gene therapy trial. 


\section{References}

Papers of special note have been highlighted as:

- of interest; $\bullet \bullet$ of considerable interest

1 Cox TM. Chapter 9 Biomarkers in lysosomal storage diseases. In: Fabry Disease: Perspectives from 5 Years of FOS. Mehta A, Beck M, Sunder-Plassmann G (Eds). Oxford PharmaGenesis, Oxford, UK (2006).

2 Germain DP. Fabry disease. Orphanet J. Rare Dis. 5 , $30(2010)$.

3 Clarke JTR. Narrative review: Fabry disease. Ann. Intern. Med. 146(6), 425-433 (2007).

- Shows a comprehensive review of Fabry disease, with details about the clinical manifestations, various treatment options and the genetics of the disease.

4 Schiffmann R, Warnock DG, Banikazemi M et al. Fabry disease: progression of nephropathy, and prevalence of cardiac and cerebrovascular events before enzyme replacement therapy. Nephrol. Dial. Transplant. 24(7), 2102-2111 (2009).

5 Human Gene Mutation Database (HGMD). www.hgmd.org

6 Wang RY, Lelis A, Mirocha J, Wilcox WR. Heterozygous Fabry women are not just carriers, but have a significant burden of disease and impaired quality of life. Genet. Med. 9(1), 34-45 (2007).

7 Echevarria L, Benistan K, Toussaint A et al. X-chromosome inactivation in female patients with Fabry disease. Clin. Genet. 89(1), 44-54 (2016).

8 Meikle PJ, Hopwood JJ, Clague AE, Carey WF. Prevalence of lysosomal storage disorders. JAMA 281(3), 249-254 (1999).

9 Spada M, Pagliardini S, Yasuda M et al. High incidence of later-onset Fabry disease revealed by newborn screening. $A m$. J. Hum. Genet. 79(1), 31-40 (2006).

10 Lin HY, Chong KW, Hsu JH et al. High incidence of the cardiac variant of Fabry disease revealed by newborn screening in the Taiwan Chinese population. Circ. Cardiovasc. Genet. 2(5), 450-456 (2009).

11 Pisani A, Visciano B, Roux GD et al. Enzyme replacement therapy in patients with Fabry disease: state of the art and review of the literature. Mol. Genet. Metab. 107(3), 267-275 (2012).

12 Arends M, Linthorst GE, Hollak CE, Biegstraaten M. Discontinuation of enzyme replacement therapy in Fabry disease in the Dutch cohort. Mol. Genet. Metab. 117(2), 194-198 (2015).

13 Deegan PB. Fabry disease, enzyme replacement therapy and the significance of antibody responses. J. Inherit. Metab. Dis. 35(2), 227-243 (2012).

14 Tanaka A, Takeda T, Hoshina T, Fukai K, Yamano T. Enzyme replacement therapy in a patient with Fabry disease and the development of $\mathrm{IgE}$ antibodies against agalsidase beta but not agalsidase alpha. J. Inherit. Metab. Dis. 33(3), 249-252 (2010).

15 Nakano S, Tsukimura T, Togawa T et al. Rapid immunochromatographic detection of serum anti- $\alpha$ galactosidase A antibodies in Fabry patients after enzyme replacement therapy. PLoS ONE 10(6), e0128351 (2015).
$16 \mathrm{Xu}$ S, Lun Y, Brignol N et al. Coformulation of a novel human $\alpha$-galactosidase A with the pharmacological chaperone AT1001 leads to improved substrate reduction in Fabry mice. Mol. Ther. 23(7), 1169-1181 (2015).

17 Rozenfeld P, Neumann PM. Treatment of Fabry disease: current and emerging strategies. Curr. Pharm. Biotechnol. 12(6), 916-922 (2011).

18 Ashe KM, Budman E, Bangari DS et al. Efficacy of enzyme and substrate reduction therapy with a novel antagonist of glucosylceramide synthase for Fabry disease. Mol. Med. 21(1), 389-399 (2015).

19 Lee CJ, Fan X, Guo X, Medin JA. Promoter-specific lentivectors for long-term, cardiac-directed therapy of Fabry disease. J. Cardiol. 57(1), 115-122 (2011).

20 Scaife M, Pacienza N, Au BC et al. Engineered human TMPK fused with truncated cell-surface markers: versatile cell-fate control safety cassettes. Gene Ther. 20(1), 24-34 (2013).

21 Biffi A, Montini E, Lorioli L et al. Lentiviral hematopoietic stem cell gene therapy benefits metachromatic leukodystrophy. Science 341(6148), 1233158 (2013).

22 Biffi A, Aubourg P, Cartier N. Gene therapy for leukodystrophies. Hum. Mol. Genet. 20(R1), 42-53 (2011).

- Shows a novel gene therapy study for metachromatic leukodystrophy patients using a lentivirus. This lysosomal storage disorder leads to severe neurodegenerative impairment.

23 Pacienza N, Yoshimitsu M, Mizue N et al. Lentivector transduction improves outcomes over transplantation of human HSCs alone in NOD/SCID/Fabry mice. Mol. Ther. 20(7), 1454-1461 (2012).

-• Describes the Fabry mouse model that was used for this research project. It also describes the lentivirus used. It is a publication by JA Medin related to the ongoing gene therapy project for Fabry disease in Canada.

24 Rodrigues LG, Ferraz MJ, Rodrigues D et al. Neurophysiological, behavioral and morphological abnormalities in the Fabry knockout mice. Neurobiol. Dis. 33(1), 48-56 (2009).

25 Taguchi A, Maruyama H, Nameta $\mathrm{M}$ et al. A symptomatic Fabry disease mouse model generated by inducing globotriaosylceramide synthesis. Biochem. J. 456(3), 373-383 (2013).

26 Ohshima T, Murray GJ, Swaim WD et al. Alphagalactosidase A deficient mice: a model of Fabry disease. Proc. Natl Acad. Sci. USA 94(6), 2540-2544 (1997).

27 Shiozuka C, Taguchi A, Matsuda J et al. Increased globotriaosylceramide levels in a transgenic mouse expressing human alpha 1,4-galactosyltransferase and a mouse model for treating Fabry disease. J. Biochem. 149(2), 161-170 (2011).

28 Nguyen Dinh Cat A, Escoubet B, Agrapart V et al. Cardiomyopathy and response to enzyme replacement therapy in a male mouse model for Fabry disease. PLoS ONE 7(5), e33743 (2012).

29 Kuchar L, Faltyskova H, Krasny L et al. Fabry disease: renal sphingolipid distribution in the $\alpha$-Gal A knockout mouse 
model by mass spectrometric and immunohistochemical imaging. Anal. Bioanal. Chem. 407(8), 2283-2291 (2015).

Auray-Blais C, Boutin M, Lavoie P et al. Gene therapy for Fabry disease patients: the importance of efficient biomarker monitoring. Mol. Gen. Metab. 108(2), S21 (2013).

31 Auray-Blais C, Cyr D, Ntwari A et al. Urinary globotriaosylceramide excretion correlates with the genotype in children and adults with Fabry disease. Mol. Genet. Metab. 93, 331-340 (2008).

32 Auray-Blais C, Boutin M. Novel $\mathrm{Gb}_{3}$ isoforms detected in urine of Fabry disease patients: a metabolomic study. Curr. Med. Chem. 19(19), 3241-3252 (2012).

-. This study by our group shows a MS metabolomic study that allowed the detection of novel Gb3 isoforms/analogs in urine. It also describes different biomarkers detected divided into five groups.

33 Manwaring V, Boutin M, Auray-Blais C. A metabolomic study to identify new globotriaosylceramide-related biomarkers in the plasma of Fabry disease patients. Anal. Chem. 85(19), 9039-9048 (2013).

-. This study by our group shows a MS metabolomic approach that allowed the detection of novel Gb3 isoforms/ analogs in plasma. We found different categories of biomarkers and elucidated their chemical structures.

Abaoui M, Boutin M, Lavoie P, Auray-Blais C. Tandem mass spectrometry multiplex analysis of methylated and nonmethylated urinary $\mathrm{Gb}_{3}$ isoforms in Fabry disease patients. Clin. Chim. Acta 452, 191-198 (2016).

35 Auray-Blais C, Millington D, Young SP, Clarke JTR, Schiffmann R. Proposed high-risk screening protocol for Fabry disease in patients with renal and vascular disease. J. Inherit. Metab. Dis. 32(2), 303-308 (2009).

36 Boutin M, Gagnon R, Lavoie P, Auray-Blais C. LC-MS/ MS analysis of plasma lyso-Gb in Fabry disease. Clin. Chim. Acta 414, 273-280 (2012).
37 Dupont FO, Gagnon R, Boutin M, Auray-Blais C. A metabolomic study reveals novel plasma lyso- $\mathrm{Gb}_{3}$ analogs as Fabry disease biomarkers. Curr. Med. Chem. 20(2), 280-288 (2013).

38 Boutin M, Auray-Blais C. Multiplex tandem mass spectrometry analysis of novel plasma lyso-Gb 3 -related analogues in Fabry disease. Anal. Chem. 86(7), 3476-3483 (2014).

39 Lavoie P, Boutin M, Auray-Blais C. Multiplex analysis of novel urinary lyso- $\mathrm{Gb}_{3}$-related biomarkers for Fabry disease by tandem mass spectrometry. Anal. Chem. 85(3), 1743-1752 (2013).

40 Auray-Blais C, Blais CM, Ramaswami U et al. Urinary biomarker investigation in children with Fabry disease using tandem mass spectrometry. Clin. Chim. Acta 438, 195-204 (2015).

41 Ferreira S, Auray-Blais C, Boutin M et al. Variations in the GLA gene correlate with globotriaosylceramide and globotriaosylsphingosine analog levels in urine and plasma. Clin. Chim. Acta 447, 96-104 (2015).

42 Boutin M, Auray-Blais C. Metabolomic discovery of novel urinary galabiosylceramide analogs as Fabry disease biomarkers. J. Am. Soc. Mass Spectrom. 26(3), 499-510 (2015).

43 Provençal P, Boutin M, Au B, Dworski S, Medin JA, Auray-Blais C. Relative distribution of a glycosphingolipid biomarker profile in NOD/SCID/Fabry mouse organs. Mol. Genet. Metab. 111(2), 11-14 (2014).

44 Sueoka H, Aoki H, Tsukimura T, Togawa T, Sakuraba H. Distributions of globotriaosylceramide isoforms, and globotriaosylsphingosine and its analogues in an $\alpha$-galactosidase A knockout mouse, a model of Fabry disease. PLoS ONE 10(12), e0144958 (2015). 